\title{
RESEARCH OF TECHNOLOGICAL PROPERTIES OF WHEAT AND SPELT GRAIN AS RAW MATERIALS FOR FLOUR AND GROATS MANUFACTURING
}

\author{
D. Zhygunov, M. Mardar, S. Sots, Yu. Barkovskaya, G. Zhyhunova \\ Odessa National Academy of Food Technologies
}

\begin{tabular}{l} 
Key words: \\
Wheat \\
Spelta \\
Hardness \\
Milling properties \\
Groats properties \\
Alveograph \\
End-use application \\
\hline
\end{tabular}

Article history:

Received 10.09.2018

Received in revised form

26.09.2018

Accepted 18.10.2018

Corresponding author:

D. Zhygunov

E-mail:

dimius75@gmail.com

\begin{abstract}
The study of two different methods of grain hardness definition of different types and varieties of wheat and spelt is presented in the article. It is shown that grain hardness is an important indicator that determines the end-use purpose of grain. There were investigated next samples of winter wheat: durum wheat of Liner variety, hard red waxy wheat of Sofiika variety; "common" hard red wheat of Kuyalnik variety; hard black wheat of Chornobrova variety; soft white wheat Bilyava; soft red wheat of Oksana variety; red spelta wheat of German origin; white spelta wheat of Zorya of Ukraine variety.

It was established that samples of durum and hard wheat (except for the Chornobrova variety) had a hardness index of more than 60 units and grinding time less $30 \mathrm{~s}$. Soft wheat and spelta had negative values of the hardness index and grinding time values more than $85 \mathrm{~s}$. The least softness among them had sample of red spelta type for both determined methods of hardness. The highest grinding time more than 2.5-3.0 times compared to soft wheat varieties had two samples of white spelta of Zorya of Ukraine variety.

A high direct correlation relationship was found between the flour yield on a CD-1 laboratory mill under the same milling conditions and the inverse correlation relationship between the yield of groats with the milling time of the 6gram grain sample $-r=0.79$ and $r=-0.73$, respectively. Between the flour yield / the groats yield and the hardness index the correlation coefficient is $-r=-0.95$ and 0.93 , respectively. Significant differences in the behavior under milling of spelta grain to patent flour and under it processing to groats in laboratory equipment are shown. The directions of the end-use of wheat and spelta grain are grounded. It is recommended using spelta grain of German origin for the production of patent flour, as well as for the production of groats. Using spelta grain of Zorya Ukraine variety is recommended for the production of flakes or for the production of whole-wheat flour.
\end{abstract}

DOI: $10.24263 / 2225-2924-2018-24-5-26$ 


\title{
ДОСЛІДЖЕННЯ ТЕХНОЛОГІЧНИХ ВЛАСТИВОСТЕЙ ПШЕНИЦІ ТА СПЕЛЬТИ ЯК СИРОВИНИ ДЛЯ ВИРОБНИЦТВА БОРОШНА І КРУПИ
}

\author{
Д.О. Жигунов, М.Р. Мардар, С.М. Соц, Ю.С. Барковська, Г.Д. Жигунова \\ Одеська начіональна академія харчових технологій
}

У статті досліджено твердозернистість різних типів і сортів зерна пшениці, у тому числі спельти, двома різними методами та показано, що твердозерність зерна - важливий показник, який обумовлює ијільове використання зерна. Досліджували тверду пшениџю сорту Лайнер, м'яку червону твердозерну ваксі-пшениџю сорту Софійка, звичайну м'яку червону твердозерну пшеницю сорту Куяльник, м'яку чорну твердозерну пшеницю сорту Чорноброва, м'яку білу м'якозерну пшеницю сорту Білява, м'яку червону м'якозерну пшеницю сорту Оксана; червону спельту німецького походження, білу спельту сорту Зоря України.

На основі проведених досліджень встановлено, що зразки твердої та твердозерної м'якої пшеничі (крім сорту Чорноброва) мали індекс твердозерності більше 60 од. при тривалості розмелу до 30 с. Сорти м'якозерної пшениці й спельти мали від'смні значення індексу твердозерності та розмелювались довще ніж за 85 с. Найменшу м'якозерність серед спельтової пшениці мав тип червоної спельти німецького походження за двома показниками твердозерності. Найбільшу тривалість подрібнення, більшу в 2,53,0 рази, якщо порівняти з м'якозерними сортами м'якої пшениці, мали два зразки білої спельти Зоря України.

Встановлено високий прямий кореляційний взаємозв'язок між виходом борошна на лабораторному млині CD-1 в однакових умовах розмелу та зворотний корелячійний взаємозв'язок між виходом дробленої крупи з тривалістю розмелу 6-грамової наважки $-r=0,79$ та $r=-0,73$ відповідно. Між виходом борошна/виходом крупи та індексом твердозерності коефіцієнт кореляції складає $r=-0,95$ та 0,93 відповідно. Показано істотні відмінності поведінки зерна спельти при його розмелі у сортове борошно та дробленні у крупу на лабораторних установках. Обтрунтовано напрями цільового використання зерна пшениці та спельти. Рекомендовано для виробниитва сортового борошна, а також для виробництва иілої або дробленої крупи використовувати спельту німецького походження, для виробництва пластівиів або для виробництва цџільнозмеленого борошна - спельту сорту Зоря Украӥни.

Ключові слова: пшениця, спельта, твердозерність, борошномельні властивості, круп'яні властивості, альвеограф, иільове використання.

Постановка проблеми. Зерно та зернові продукти відіграють важливу роль у харчуванні, забезпечують більше половини щоденного споживання енергії в усьому світі. Серед усіх зернових пшениця займає перші позиції, оскільки зерно містить білок з винятковими фізичними та хімічними власти- 
востями, здатний при гідратації набухати й утворювати еластичну, пружну, розтяжну масу - клейковину. Залежно від ретельності промивання сухі речовини клейковини містять $75-85 \%$ білка (переважно гліадіну та глютеніну [1]), 5-10\% ліпідів. Велика частина залишку — крохмаль і некрохмальні вуглеводи. Білки гліадину та глютеніну не розчинюються у воді, але екстрагуються етанолом і лугом та характеризуються високим рівнем глютамінів і залишків проліну [2]. Різні види, типи та сорти пшениці відрізняються за вмістом білка, його складом і розподілом клейковинних та неклейковинних білків, за вмістом крохмалю, співвідношенням його структурних компонентів - амілози та амілопектину. Через це вони мають різні фізико-технологічні й хіміко-технологічні властивості.

Щорічно вирощується близько 700 млн т пшениці, з якої 95\% припадає на Triticum aestivum - гексаплоїдний вид (геноми AABBDD), який називають «звичайною» або «хлібною» пшеницею [3]. У цієї пшениці розрізняють твердозерні та м'якозерні типи, останні використовують для виробництва кондитерських виробів [4; 5]. Крім того, щорічно вирощується близько 35-40 млн т Triticum turgidum var. Durum - тетраплоїдний вид, пристосований до гарячих сухих умов навколо Середземного моря та подібного клімату в інших регіонах. Ця пшениця використовується, головним чином, для виготовлення макаронних виробів, тому її часто називають «пшеничною макаронною» або «твердою пшеницею».

Інші більш «стародавні» види пшениць, які використовували раніше, сьогодні вирощують лише на невеликих територіях. Їх широко застосовують у селекції звичайних пшениць, для виробництва традиційних продуктів харчування (борошна та круп) їх практично не використовують, але останнім часом знову зацікавилися тим, що ці пшениці можуть бути багатими на біологічно активні компоненти і тому підходять для виробництва високоякісних продуктів харчування 3 підвищеними корисними властивостями для здоров'я [6]. Найбільш відомі та широко вивчені зі «стародавніх» пшениць: диплоїдна пшениця однозернянка (Triticum mоnососсит var. Monococcum genome AA), тетраплоїдна (як дурум) пшениця еммер (T. turgidum var. Dicoccum genomes AABB), яку також називають полбою, та гексаплоїдна пшениця спельта ( $T$. aestivum var. Spelta genomes AABBDD), яка має такий же набір геномів, що й хлібна пшениця. Спельта, емер і більшість форм однозернянок відрізняються від хлібної та макаронної пшениць тим, що їх оболонки залишаються щільно закритими над зернівками і не видаляються при обмолоті [3].

Технологічні показники якості пшениці, що обгрунтовують іiі подальше цільове використання, поділені на дві групи: фізико-технологічні та хімікотехнологічні. Склоподібність зерна, колір, маса 1000 зерен, натура, форма та твердозерність $є$ важливими фізичними характеристиками, які впливають на якість зерна пшениці як об'єкта переробки на борошно, крупи або макаронні вироби $[7 ; 8]$. Хімічні характеристики включають вміст білка, показник седиментації, кількість та якість клейковини, число падіння тощо та обумовлюють споживні властивості готових продуктів харчування. Це стосується зерна. При оцінці якості борошна оцінюють також реологічні властивості тіста та показники пробної випічки хліба [9]. 
Консистенція ядра є однією з найважливіших характеристик для розмелювання або подрібнення зерна, також вона впливає на хлібопекарські властивості пшениці. На основі твердості (твердозерності) ядра пшениця класифікується як м'якозерна, змішана (напівтвердозерна), твердозерна та дурум [10, с. 50]. Ця класифікація є основоположною для диференціації світової торгівлі пшеничним зерном [7]. Твердозерна пшениця більш підходить для дріжджового хліба, оскільки пошкоджений крохмаль поглинає більше води, тоді як борошно м'якозерної пшениці краще використовувати для печива та тістечок.

Ядро м'якозерної пшениці легко подрібнюється, що призводить до виробництва великої кількості непошкоджених гранул крохмалю. Борошно з більш грубою текстурою виробляється з твердозерної пшениці, з більшою кількістю зруйнованих крохмальних зерен і з більшими енерговитратами при помелі. Чим твердіше зерно, тим триваліше воно подрібнюється.

Довгий час в Україні вирощувалася і селекціонувалися звичайна хлібопекарська пшениця, яка сьогодні використовується для виробництва всього асортименту харчової продукції: подрібненої крупи, пластівців, борошна не тільки для хлібобулочних, але й для кондитерських, макаронних виробів, хоча в усьому світі прийнята практика цільового використання зерна. У зв'язку з цим у Селекційно-генетичному інституті (СГI) - Національному центрі насіннєзнавства та сортовивчення Української академії аграрних наук, Інституті рослинництва ім. В.Я. Юр'єва НААН, Всеукраїнському науковому інституті селекції (BНIC) та ін. створені і зареєстровані в Державному реєстрі сортів рослин, придатних для поширення в Україні, нові види і типи пшениць, хоча напрями використання деяких у тому ж реєстрі не вказані. Основна частина наукових праць вітчизняних вчених присвячена вивченню агрономічних властивостей і хімічного складу пшениць, зокрема їхніх технологічних властивостей як об'єктів переробки $[11 ; 12]$, однак порівняльного дослідження борошномельних, круп'яних і хлібопекарських властивостей проведено не було.

Мета статті: провести порівняльні дослідження борошномельних, хлібопекарських та круп'яних властивостей різних видів і типів пшениці для обгрунтування напрямів їх подальшої переробки.

Матеріали і методи. Предметом досліджень були обрані 10 зразків пшениці врожаю 2016 р. і 2017 р.: 1-й зразок - тверда (дурум) пшениця сорту Лайнер (2016р.); 2-й зразок — м'яка червона твердозерна ваксі пшениця сорту Софійка (2016 р.); 3-й та 4-й зразки - м'яка червона твердозерна пшениця сорту Куяльник (2016 р., 2017 р.); 5-й зразок — м'яка чорна твердозерна пшениця сорту Чорноброва (2016р.); 6-й зразок - м'яка біла м'якозерна пшениця сорту Білява (2016 р.); 7-й зразок — м'яка червона м'якозерна пшениця сорту Оксана (2016 р.); 8-й зразок - червона спельта німецького походження; 9-й та 10-й зразки - біла спельта сорту Зоря України (2016, 2017 р.). Це перший вітчизняний сорт, селекціонований під керівництвом Ф.М. Парія у BHIC. Зразки плівчастих пшениць (8-10), які надійшли на дослідження, були попередньо обрушені.

Для дослідження фізико-хімічних показників зерна (вологість, зольність) використовували стандартні методики: вологість зерна шляхом висушування в сушильній шафі при температурі $130^{\circ} \mathrm{C}$ згідно з ГОСТ $13586.5-93$ та 
ГОСТ 9404-88, зольність зерна і продуктів його переробки - озолінням у муфельній печі при температурі $800^{\circ} \mathrm{C}$ згідно з ГОСТ 10847-74 та ГОСТ 27494-87. Твердозерність зерна оцінювали двома методами: твердозерність за швидкістю розмелу - тривалістю подрібнення наважки 6 г зерна на установці Brabender Automatic Micro Hardness Tester згідно з [13]. Для цього зважували наважку зерна приблизною вагою 10 г, встановлювали ваги, а потім подрібнювали на установці Brabender та вимірювали час, за який подрібнюється 6 г зерна. Твердозерність за ІЧ - шляхом аналізу зразка подрібненого зерна на аналізаторі Inframatic 8600, використовуючи його стандартні калібровки.

Борошномельні властивості оцінювали за результатами лабораторного помелу на млині CD-1, який складається з двох половин: драної та розмельної частин. При розмелі зерно однократно проходить крізь три рифлених вальця, потім просіюється на бураті, який має два сита - для отримання драних висівок, крупки та драного борошна. Розмельна частина оснащена парою вальців для подрібнення крупки, а також буратом для відокремлення борошна від розмельних висівок. Згідно з інструкцією до млину для отримання стандартного виходу борошна від 60 до 70\% здійснювали двократний пропуск крупки.

Круп'яні властивості оцінювали за результатами отримання дробленої крупи на лабораторному подрібнювачі Falling Number $\mathrm{AB}$ з подальшим провіюванням на аспіраційній установці Paul Polikeit, яка дає змогу відібрати три фракції крупи: найкрупніша фракція відноситься до дробленої крупи, інші дві дрібні фракції (дрібка) та мучка - до побічних продуктів. Чим вищий вихід першої фракції, тим кращі круп'яні властивості зерна.

Перед проведенням випробувань борошномельних і круп'яних властивостей зерно очищували від зернової та сміттєвої домішок. Твердозерні сорти пшениці (зразки 1-5) перед помелом зволожували до 16,0\%, м'якозерні сорти пшениці та спельти (зразки 6-10) - до 15,0\% з відволоженням 24 та 16 год відповідно. При отриманні дробленої крупи зерно додатково не зволожували.

Кількість води $(K)$, необхідної для зволоження, визначали за формулою:

$$
K=m^{*}((100-W 0) /(100-W \mathrm{I})-1),
$$

де $m$ - маса зерна, г; $W 0-$ вологість зерна вихідна, $\%$; $W I-$ вологість зерна перед помелом, \%.

Реологічні властивості тіста оцінювали на альвеографі згідно з процедурою ISO-27971 без адаптивного зволоження на підставі вологості сортового борошна, отриманого при помелі на лабораторному млині CD-1. Водопоглинальну здатність оцінювали на міксолабі згідно з ISO-17718.

Результати і обговорення. Досліджені зразки зерна за показниками твердозерності (табл. 1) чітко розділились на дві групи: зразки твердої та твердозерної м'якої пшениці (крім сорту Чорноброва) мали індекс твердозерності за ІЧ-аналізатором (HI - hardness index) більше 60 од. при тривалості розмелу до 30 с. Сорт Чорноброва незначно поступався сорту Куяльник - тривалість розмелу 6-грамового зразка була лише на $12-15$ с більша, а індекс твердозерності за ІЧ-аналізатором складав 48 од.

Сорти м'якозерної пшениці та спельти мали від'ємні значення НІ та розмелювались довше ніж за 85 с. Найменшу м'якозерність серед спельтової 
пшениці мав тип червоної спельти за двома показниками твердозерності. Найбільшу тривалість подрібнення, більшу в 2,5-3,0 рази, якщо порівняти 3 м'якозерними сортами м'якої пшениці, мали два зразки спельти Зоря України.

Таблиця 1. Показники якості зерна різних сортів пшениці та спельти

\begin{tabular}{|c|c|c|c|c|}
\hline Назва зразка & $\begin{array}{c}\text { Вологість } \\
\text { вихідного } \\
\text { зерна, \% }\end{array}$ & $\begin{array}{c}\text { Вологість зерна } \\
\text { перед } \\
\text { помелом*, \% }\end{array}$ & $\begin{array}{c}\text { Тривалість } \\
\text { розмелу 6 г, } \\
\text { с }\end{array}$ & $\begin{array}{c}\text { Індекс } \\
\text { твердозерності } \\
\text { за ІЧ- } \\
\text { аналізатором, } \\
\text { од. }\end{array}$ \\
\hline 1. Лайнер & 12,0 & 16,0 & 18 & 166 \\
\hline 2. Софійка & 12,1 & 16,0 & 23 & 70 \\
\hline 3. Куяльник 2016 р. & 12,5 & 16,0 & 24 & 67 \\
\hline 4. Куяльник 2017 р. & 11,4 & 16,0 & 27 & 61 \\
\hline 5. Чорноброва & 12,3 & 16,0 & 39 & 48 \\
\hline 6. Білява & 13,0 & 15,0 & 88 & -33 \\
\hline 7. Оксана & 12,5 & 15,0 & 102 & -33 \\
\hline 8. Червона спельта & 13,0 & 15,0 & 85 & -14 \\
\hline 9. Зоря України 2016 р. & 13,5 & 15,0 & 212 & -25 \\
\hline 10. Зоря України 2017 р. & 13,3 & 15,0 & 278 & -39 \\
\hline
\end{tabular}

Примітка: * згідно з розрахунками розрахункового значення у результаті зволоження зерна перед помелом.

Оскільки для розмелу зерна застосовували лабораторний млин CD-1, то вихід борошна при однаковій кількості проходів через вальці: однократно на драній стороні, та двічі — на розмельної стороні зростав прямо пропорційно зменшенню твердозерності зерна: коефіцієнт кореляції виходу сортового борошна 3 тривалістю розмелу 6-грамової наважки $-r=0,79,3$ індексом твердозерності - $r=-0,95$.

Зерно сортів Лайнер і Софійка внаслідок своєї твердості і при однакових умовах розмелювання та просіювання порівняно 3 іншими зразками не встигало подрібнюватись, про що свідчить велика кількість (42,0-47,0\%) висівок. Тільки для цих двох зразків у зворотнихх умовах помелу кількість розмельних висівок перевищувала кількість драних висівок, а кількість борошна була меншою 60\% (табл. 2). При помелі зразків м'якої твердозерної пшениці сорту Куяльник і Чорноброва (яка створена на основі схрещування пшениці Куяльник 3 пшеницею DONG 10 китайського походження) вихід борошна знаходився в межах, прописаних інструкцією до млина (60-70\%), а відношення виходу драних до розмельних висівок складало 1,02-1,21, що також свідчить про недостатнє подрібнення зерна, тому що у виробничих умовах це співвідношення складає 1,5-2,0.

При помелі сортів м'якозерної пшениці та спельти вихід борошна перевищував 70\%, тобто для забезпечення цієї норми виходу борошна, що рекомендована при розмелі зерна на CD-1, для м'якозерної пшениці та спельти достатній одноразовий пропуск крупки крізь розмельні вальці. Проте при майже однаковому високому виходу борошна характер подрібнення сортів Білява та Оксана істотно відрізнявся від спельтового зерна. М'якозерні сорти вимелювались дуже погано, утворюючи значну кількість драних висівок - 
більшу у 2,58-3,19 раза за кількість розмельних висівок. Спельтові пшениці при більшому виході борошна утворювали висівки з гарним співвідношенням між драними та розмельними, тобто їх розмелювання відбувалося легше, що при виробництві сортового борошна в промислових умовах потребує більш короткої схеми як драного, так і розмельного процесів.

Таблиця 2. Вихід продуктів на лабораторному млині CD-1 з різних сортів пшениці та спельти

\begin{tabular}{|c|c|c|c|c|}
\hline Назва зразка & $\begin{array}{c}\text { Вихід } \\
\text { сортового } \\
\text { борошна, \% }\end{array}$ & $\begin{array}{c}\text { Вихід } \\
\text { висівок, \% }\end{array}$ & $\begin{array}{c}\text { Загальний } \\
\text { вихід, \% }\end{array}$ & $\begin{array}{c}\text { Відношення } \\
\text { виходу драних / } \\
\text { розмельних } \\
\text { висівок }\end{array}$ \\
\hline 1. Лайнер & 53,0 & 47,0 & 100,0 & 0,92 \\
\hline 2. Софійка & 58,0 & 42,0 & 100,0 & 0,94 \\
\hline 3. Куяльник 2016 p. & 61,2 & 38,8 & 100,0 & 1,03 \\
\hline 4. Куяльник 2017 р. & 63,9 & 36,1 & 100,0 & 1,02 \\
\hline 5. Чорноброва & 67,6 & 32,5 & 100,0 & 1,21 \\
\hline 6. Білява & 71,1 & 28,9 & 100,0 & 3,19 \\
\hline 7. Оксана & 69,8 & 30,3 & 100,0 & 2,58 \\
\hline 8. Червона спельта & 72,1 & 27,9 & 100,0 & 1,31 \\
\hline 9. Зоря України 2016 р. & 72,2 & 27,9 & 100,0 & 1,44 \\
\hline 10. Зоря України 2017 р. & 73,3 & 26,7 & 100,0 & 2,12 \\
\hline
\end{tabular}

При вивченні круп'яних властивостей (табл. 3) встановлено, що чим вища твердозерність, тим вищий вихід дробленої крупи: коефіцієнт кореляції виходу дробленої крупи з тривалістю розмелу 6-грамової наважки $-r=-0,73$, 3 індексом твердозерності - 0,93. За виходом крупи м'якозерні сорти пшениці поступаються твердозерним. Зерно спельти також володіє невисокими круп'яними властивостями. Серед досліджених зразків спельти найкращі круп'яні властивості притаманні більш твердозерній червоній спельті німецького походження.

Таблиця 3. Вихід продуктів при отриманні дробленої крупи з різних сортів пшениці та спельти

\begin{tabular}{|c|c|c|c|}
\hline Назва зразка & $\begin{array}{c}\text { Вихід } \\
\text { дробленої крупи, \% }\end{array}$ & $\begin{array}{c}\text { Вихід } \\
\text { дрібки та мучки, } \%\end{array}$ & $\begin{array}{c}\text { Загальний } \\
\text { вихід, } \%\end{array}$ \\
\hline 1. Лайнер & 88,4 & 11,6 & 100,0 \\
\hline 2. Софійка & 86,9 & 13,1 & 100,0 \\
\hline 3. Куяльник 2016 p. & 83,8 & 16,2 & 100,0 \\
\hline 4. Куяльник 2017 p. & 81,8 & 18,2 & 100,0 \\
\hline 5. Чорноброва & 81,5 & 18,5 & 100,0 \\
\hline 6. Білява & 75,2 & 24,8 & 100,0 \\
\hline 7. Оксана & 74,5 & 25,5 & 100,0 \\
\hline 8. Червона спельта & 78,6 & 21,4 & 100,0 \\
\hline 9. Зоря України 2016 р. & 74,7 & 25,3 & 100,0 \\
\hline 10. Зоря України 2017 р. & 75,5 & 24,5 & 100,0 \\
\hline
\end{tabular}

Як видно 3 табл. 4, зольність борошна 3 твердозерної м'якої пшениці Куяльник складала $0,39-0,40 \%$, що значно менше, ніж у виробничих умовах, 
та обумовлено як низькою зольністю зерна, так і низьким виходом борошна при розмелі на млині CD-1 за стандартною процедурою. Зольність борошна твердої та ваксі-пшениці сортів Лайнер і Софійка перевищувала зольність борошна м'якої твердозерної пшениці, а зольність м'якозерних сортів Білява та Оксана, навпаки, була меншою, що узгоджується $з$ даними [14; 15]. Зольність усіх зразків сортового спельтового борошна була вищою за норми зольності для вищого сорту $0,55 \%$, що обумовлено іiі високим виходом в умовах експерименту.

Зольність дробленої крупи для всіх досліджених зразків перевищувала іiі значення у вихідному зерні внаслідок утворення незначної кількості мучки при дробленні зерна. При цьому, незважаючи на більший вихід мучки із зерна спельти, зольність спельтової крупи була найбільшою - 1,84-2,07\%.

Таблищя 4. Зольність зерна і продуктів із різних сортів пшениці та спельти

\begin{tabular}{|c|c|c|c|}
\hline Назва зразка & Зольність зерна, \% & $\begin{array}{c}\text { Зольність сортового } \\
\text { борошна, } \%\end{array}$ & $\begin{array}{c}\text { Зольність дробленої } \\
\text { крупи, \% }\end{array}$ \\
\hline 1. Лайнер & 1,56 & 0,51 & 1,59 \\
\hline 2. Софійка & 1,54 & 0,48 & 1,60 \\
\hline 3. Куяльник 2016 р. & 1,36 & 0,40 & 1,45 \\
\hline 4. Куяльник 2017 р. & 1,40 & 0,39 & 1,51 \\
\hline 5. Чорноброва & 1,52 & 0,48 & 1,63 \\
\hline 6. Білява & 1,51 & 0,41 & 1,66 \\
\hline 7. Оксана & 1,47 & 0,45 & 1,62 \\
\hline 8. Червона спельта & 1,73 & 0,57 & 1,84 \\
\hline 9. Зоря України 2016 р. & 1,89 & 0,62 & 2,07 \\
\hline 10. Зоря України 2017 р. & 1,89 & 0,60 & 2,04 \\
\hline
\end{tabular}

За результатами аналізу реологічних властивостей тіста на альвеографі (табл. 5), як і очікувалось, встановлено, що найкращі хлібопекарські властивості притаманні борошну з пшениці сорту Куяльник - показник W складав 439 та 372 од.ал., а показник конфігурації альвеограми P/L не перевищував значення 1,2. Тісто мало високу еластичність, що також добре для хліба, але не підходить для деяких інших виробів, наприклад, для піци.

Борошно з пшениці Чорноброва має задовільну еластичність - $\mathrm{Ie}=39,0$, меншу пружність $P$, краще співвідношення $P / L$, але невисокі значення показника $W$ - 137 од.ал., тому його самостійно для випічки хліба застосовувати нераціонально, але у кількості 20-30\% у складі композитної суміші з борошном 3 хлібопекарської пшениці борошно із сорту Чорноброва може використовуватись як поліпшувач не тільки біологічної цінності, але й технологічної якості хліба.

Борошно з твердої пшениці Лайнер і твердозерної ваксі-пшениці Софійка при застосуванні стандартного протоколу альвеографа не змогло реалізувати свій потенціал внаслідок значної відмінності від хлібопекарського борошна, насамперед через високу водопоглинальну здатність (ВПЗ) - 63\% та 67\%, відповідно, у порівнянні з 58,5\% у борошні з сорту Куяльник. Тому, також як і для борошна 3 пшениці Чорноброва, борошно з ваксі-пшениці рекомендується застосовувати для коригування хлібопекарської сили звичайного борошна, 
наприклад, для підвищення ВПЗ композитного борошна, якщо хлібопекарське борошно має ВПЗ менше 57,0\% або для виробництва макаронних виробів 3 більшою гранулометрію борошна $з$ твердої та ваксі-пшениці.

Борошно з м'якозерної пшениці мало відповідну розтяжність, невисоке значення коефіцієнта $P / L-0,74-0,81$, але низьку «хлібопекарську силу» $W=155-162$ од, низьку ВПЗ - 52-53,5\%. Усі зразки спельтового борошна мали ще меншу міцність, низьку еластичність і низьку здатність до випічки хліба. ВПЗ спельтового борошна знаходилась у межах $50-51,5 \%$. При таких значеннях альвеограми застосування борошна як сировини для кондитерських виробів, вафельних виробів, пряників, кексів обмежене. Адже для цих виробів потрібне в'язке або в'язко-пластичне тісто.

Таблиця 5. Показники аналізу сортового борошна на альвеографі з різних сортів пшениці та спельти

\begin{tabular}{|c|c|c|c|c|}
\hline Назва зразка & $\begin{array}{c}\text { Сила борошна } \\
W, \text { од. ал. }\end{array}$ & Коефіцієнт $P / L$ & $\begin{array}{c}\text { Індекс } \\
\text { розтяжності } G\end{array}$ & $\begin{array}{c}\text { Індекс еластич- } \\
\text { ності Іе, \% }\end{array}$ \\
\hline 1. Лайнер & 132 & 3,82 & 15,2 & 31,2 \\
\hline 2. Софійка & 199 & 4,30 & 14,7 & 20,2 \\
\hline 3. Куяльник 2016 р. & 439 & 1,11 & 22,5 & 67,6 \\
\hline 4. Куяльник 2017 p. & 372 & 1,17 & 22,3 & 69,5 \\
\hline 5. Чорноброва & 137 & 1,03 & 18,2 & 39,0 \\
\hline 6. Білява & 162 & 0,81 & 19,8 & 49,0 \\
\hline 7. Оксана & 155 & 0,74 & 20,3 & 42,4 \\
\hline 8. Червона спельта & 52 & 0,52 & 18,5 & 21,7 \\
\hline 9. Зоря України 2016 р. & 62 & 0,25 & 24,2 & 29,5 \\
\hline 10. Зоря України 2017 р. & 50 & 0,50 & 17,5 & 28,9 \\
\hline
\end{tabular}

\section{Висновки}

1. При аналізі різних типів і сортів зерна встановлено високий прямий кореляційний взаємозв'язок між виходом борошна на лабораторному млині CD-1 в однакових умовах розмелу та зворотний кореляційний взаємозв'язок між виходом дробленої крупи на лабораторному подрібнювачі Falling Number $\mathrm{AB}$ з тривалістю розмелу 6-грамової наважки $-r=0,79$ та $r=-0,73$ відповідно. Між виходом борошна/виходом крупи та індексом твердозерності коефіцієнт кореляції складає $r=-0,95$ та 0,93 відповідно.

2. Підтверджено використання твердозерності зерна для обгрунтування цільового використання зерна. Показано, що за цим показником спельта відноситься до м'якозерних сортів. За сукупністю технологічних показників рекомендовано лінію спельти німецького походження використовувати для виробництва борошна, а також для виробництва цілої або дробленої крупи; спельту сорту Зоря України - для виробництва пластівців або для виробництва цільнозмеленого борошна.

3. За реологічними властивостями тіста рекомендовано використання борошна $з$ пшениці Чорноброва, а також твердозерної ваксі-пшениці Софійка у складі композитних сумішей з борошном хлібопекарської пшениці у кількості $20-30 \%$ для коригування iї властивостей в тому чи іншому напряму. 
При їх самостійному використанні очікуються низькі показники хлібобулочних виробів. М'якозерні сорти м'якої пшениці та спельти доцільно застосовувати як сировину для кондитерських виробів, вафельних виробів, пряників, кексів, для яких характерне в'язке або в'язко-пластичне тісто.

\section{Література}

1. Biesiekierski J.R. What is gluten? J. Gastroenterol. Hepatol. 2017. Vol. 32. P. 78-81.

2. Wieser H. Chemistry of gluten proteins. Food Microbiol. 2007. Vol. 24, No. 2. P. 115 119.

3. Shewry P.R., Hey S. Do "ancient" wheat species differ from modern bread wheat in their contents of bioactive components? J. Cereal Sci. Elsevier Ltd, 2015. Vol. 65. P. 236-243.

4. Ozturk S. et al. Predicting the cookie quality of flours by using Mixolab®. Eur. Food Res. Technol. 2008. Vol. 227, No. 5. P. 1549-1554.

5. Gaines C.S. Associations Among Soft Wheat Flour Particle Size, Protein Content, Chlorine Response, Kernel Hardness, Milling Quality, White Layer Cake Volume, and SugarSnap Cookie Spread. Cereal Chem. 1985. Vol. 62, No. 4. P. 290-292.

6. Ruibal-Mendieta N.L. et al. Spelt (Triticum aestivum ssp. spelta) as a source of breadmaking flours and bran naturally enriched in oleic acid and minerals but not phytic acid. J. Agric. Food Chem. 2005. Vol. 53, No. 7. P. 2751-2759.

7. Pasha I., Anjum F.M., Morris C.F. Grain hardness: A major determinant of wheat quality. Food Sci. Technol. Int. 2010. Vol. 16, No. 6. P. 511-522.

8. Gaines C.S. et al. Predicting a hardness measurement using the single-kernel characterization system. Cereal Chem. 1996. Vol. 73, No. 2. P. 278-283.

9. Лебеденко Т.Є., Пшенишнюк Г.Ф., Соколова Н.Ю. Технологія хлібопекарського виробництва. Практикум. Одеса: Освіта України, 2014. 392 р.

10. RosentrAter K.A., Evers A.D. KENT'S TECHNOLOGY OF CEREALS. Fifth edit. Woodhead Publishing, 2017. 900 p.

11. Семенюк И.В., Чеботарь С.В., Рыбалка А.И., Сиволап Ю.М. Молекулярно-генетический анализ селекционных линий мягкой пшеницы с крахмалом амилопектинового типа. Цитология и Генетика, 2011, № 5, 17-22.

12. Господаренко Г.М., Полторецький С.П., Любич В.В. ті ін. Характеристика твердості та міцності зернівок пшениці спельти залежно від сорту та лінії. Вісник аграрної науки Причорномор'я. 2017. Вип. 93. С. 86-94.

13. Miller B.S., Pomeranz Y., Afework S. Hardness (texture) of hard red winter-wheat grown in a soft wheat area and of soft red winter-wheat grown in a hard wheat area. Cereal Chemistry. 1984. Vol. 61, No. 2. P. 201-203.

14. Ahmed R. et al. Comparative study on the physicochemical and rheological parameters of soft wheat flour obtained from three countries. Am. J. Food Sci. Nutr. Res. 2015. Vol. 2, No. 3. P. $89-93$.

15. Graybosch R.A. et al. Functional properties of waxy wheat flours: Genotypic and environmental effects. J. Cereal Sci. 2003. Vol. 38, No. 1. P. 69-76. 